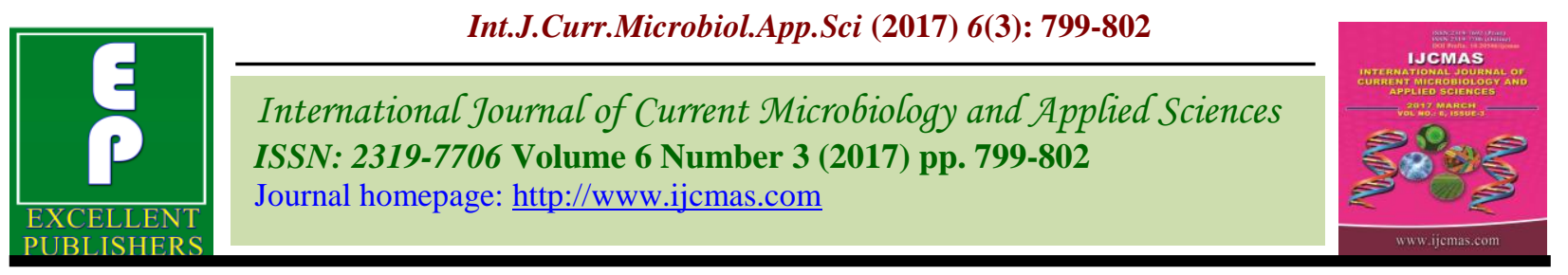

Original Research Article https://doi.org/10.20546/ijcmas.2017.603.093

\title{
Effect of Sowing Dates and Varieties on Quality and Economics of Indian Mustard (Brassica juncea L.)
}

\author{
Abhinaw Kumar Singh ${ }^{1}$, Hanumant Singh ${ }^{2}$, Sarware Alam $^{3}$, \\ O.P. Rai ${ }^{4}$ and Ghanshyam Singh ${ }^{4}$ \\ ${ }^{1}$ Department of Agronomy, ${ }^{2}$ Department of Soil Science, Narendra Deva University of \\ Agriculture and Technology, Kumarganj, Faizabad (U.P.) 224229 - India \\ ${ }^{3}$ Department of Soil Science, Sam Higgin bottom Institute of Agriculture, Technology and \\ Sciences, Allahabad, (U.P.) 211007 - India \\ ${ }^{4}$ Department of Agronomy Narendra Deva University of Agriculture and Technology, \\ Kumarganj, Faizabad (U.P.) 224229 - India \\ *Corresponding author:
}

\section{A B S T R A C T}

\section{Keywords}

Indian mustard, Sowing dates,

Varieties, Quality, Economics.

Article Info

Accepted:

15 February 2017

Available Online:

10 March 2017
A field experiment consisting of four dates of sowing and five varieties in split plot design. The result revealed that highest oil content $\%$ and economic return was computed under $25^{\text {th }}$ October sowing, with Coral-437 variety. $25^{\text {th }}$ October sowing with Coral-437 variety proved that the most qualitative and economically feasible for cultivation of Indian mustard.

\section{Introduction}

Rape seed and mustard are usually sown by the end of September to second fortnight of October in north India when grown as a sole crop or on dates of the main crop when sown as mixed or intercrop. But, with the development of new varieties of crops and adoption of multiple cropping systems under irrigated condition, it has become essential to extend their sowing from October to mid of November or even later. Singh and Singh (2002) conducted a field experiment at Faizabad (Uttar Pradesh) and recorded highest over yield with $14^{\text {th }}$ October sowing as compared to $29^{\text {th }}$ October, $13^{\text {th }}$ November and $28^{\text {th }}$ November sowing.

Delayed sowing would influence adversely the crop performance owing to change in abiotic and biotic environmental conditions. It necessitates developing suitable agro techniques to augment the productivity of the crop. Among the different agronomic practices, optimum sowing time plays an important role to fully exploit the genetic potentiality of a variety as it provides optimum crop growing environment such as 
temperature, humidity and light etc. Sowing time is one of the most important nonmonetary input which influences to a great extent on both the quality and economics of Indian mustard. Jadhav and Singh (1992) from IARI, New Delhi reported that $18^{\text {th }}$ October sowing recorded higher benefit cost ratio (1.42) as compared to $17^{\text {th }}$ November sowing (0.81).

\section{Materials and Methods}

A field experiment was conducted during the rabi season 2011 - 2012 at Agronomy Research Farm, Narendra Deva University of Agriculture and Technology, Kumarganj, Faizabad (U.P.) with four sowing dates as main plotsviz.25 September,05 October,15 October, and 25 October 2011andfive varieties viz.,Rohini,Kranti,Coral-437, Maya and PBR-357as subplots, designed in split lot with three replications. All varieties belong to
(Brassica juncea) Indian mustard. The crop was fertilized with a uniform dose of nitrogen, phosphorus and potassium@120, 60 , and $40 \mathrm{kgha}^{-1}$ respectively.Sulphur was applied as per treatment through elemental sulphur.

\section{Results and Discussion}

The quality of mustard seeds was measured in the term of oil and protein contents which were markedly influenced by dates of sowing. Oil content was significantly higher under $25^{\text {th }}$ October sown crop as compared to $05^{\text {th }}$ October and $25^{\text {th }}$ September sown crop. Protein content was not significantly influenced due to dates of sowing. The findings are in close proximity of Ghanbahadur et al., 2006. The quality of mustard oil and protein contents was not significantly influenced due to varieties.

Table.1 Effect of treatment on quality of Indian mustard

\begin{tabular}{lcc}
\hline Treatments & Oil content (\%) & Protein content (\%) \\
\hline Date of sowing & 33.93 & 20.84 \\
D1 (25 Sep.) & 40.06 & 21.39 \\
D2 (05 Oct.) & 41.17 & 21.98 \\
D3 (15 Oct.) & 41.62 & 22.22 \\
D4 (25 Oct.) & 1.19 & 0.67 \\
SEm \pm & 4.11 & 2.32 \\
CD (P=0.05) & & \\
Varieties & 38.57 & 21.16 \\
V1 (Rohini) & 39.00 & 21.39 \\
V2 (Kranti) & 39.80 & 21.90 \\
V3 (Coral-437) & 38.89 & 21.81 \\
V4 (Maya) & 39.72 & 21.77 \\
V5 (PBR-357) & 1.07 & 0.58 \\
SEm \pm & 3.09 & 1.68 \\
CD (P= 0.05) & NS & NS \\
D X V & & \\
\hline
\end{tabular}


Int.J.Curr.Microbiol.App.Sci (2017) 6(3): 799-802

Table.2 Effect of treatment on economics of Indian mustard

\begin{tabular}{lcccccc}
\hline $\begin{array}{l}\text { Treatments } \\
\text { combination }\end{array}$ & $\begin{array}{c}\text { Grain yield } \\
\text { (q h-1) }\end{array}$ & $\begin{array}{c}\text { Stover yield } \\
\text { (q ha1) }\end{array}$ & $\begin{array}{c}\text { Cost of cul } \\
\text { (Rs. ha-1) }\end{array}$ & $\begin{array}{c}\text { tivation } \\
\text { (Rs. ha-1) }\end{array}$ & $\begin{array}{c}\text { Net return } \\
\text { (Rs. ha-1) }\end{array}$ & Batio \\
\hline D1V1 & 12.62 & 39.47 & 23213.74 & 48117.00 & 24903.26 & 1.07 \\
D1V2 & 13.59 & 42.50 & 23213.74 & 51815.00 & 28601.26 & 1.23 \\
D1V3 & 15.15 & 47.36 & 23213.74 & 57761.00 & 34547.26 & 1.49 \\
D1V4 & 13.01 & 40.68 & 23213.74 & 49603.00 & 26389.26 & 1.14 \\
D1V5 & 15.73 & 49.18 & 23213.74 & 59973.00 & 36759.26 & 1.58 \\
D2V1 & 14.18 & 44.33 & 23213.74 & 54063.00 & 30849.26 & 1.33 \\
D2V2 & 15.73 & 49.18 & 23213.74 & 59973.00 & 36759.26 & 1.58 \\
D2V3 & 16.12 & 50.40 & 23213.74 & 61460.00 & 38247.26 & 1.65 \\
D2V4 & 14.37 & 44.93 & 23213.74 & 54788.00 & 31574.26 & 1.36 \\
D2V5 & 16.70 & 52.22 & 23213.74 & 63672.00 & 40458.26 & 1.74 \\
D3V1 & 16.12 & 50.40 & 23213.74 & 61460.00 & 38246.26 & 1.65 \\
D3V2 & 17.28 & 54.04 & 23213.74 & 65884.00 & 42670.26 & 1.84 \\
D3V3 & 18.64 & 58.29 & 23213.74 & 71069.00 & 47855.26 & 2.06 \\
D3V4 & 16.51 & 51.61 & 23213.74 & 62946.00 & 39732.26 & 1.71 \\
D3V5 & 17.67 & 55.26 & 23213.74 & 67371.00 & 44157.26 & 1.90 \\
D4VI & 17.09 & 53.43 & 23213.74 & 65158.00 & 41944.26 & 1.81 \\
D4V2 & 18.06 & 56.47 & 23213.74 & 68857.00 & 45643.26 & 1.97 \\
D4V3 & 20.59 & 64.36 & 23213.74 & 78501.00 & 55287.26 & 2.38 \\
D4V4 & 17.28 & 54.04 & 23213.74 & 65884.00 & 42670.26 & 1.84 \\
D4V5 & 19.42 & 60.72 & 23213.74 & 74042.00 & 50828.26 & 2.19 \\
\hline
\end{tabular}

The cost of cultivation was calculated (Rs.23213.74ha ${ }^{-1}$ ) in all the treatments. The highest net return (Rs. 55287.26 ha ${ }^{-1}$ ) was recorded with crop sown on $25^{\text {th }}$ October with Coral-437 variety followed by the same sowing date with PBR-357 the similar trend was also noted in gross income.

The highest net incomes per rupees invest i.e. (2.38) was recorded sowing on $25^{\text {th }}$ October with Coral-437 variety followed by the same sowing date with PBR-357 (2.19) the results are in close accordance with Iraddi and Mansur (2008).

\section{References}

Ghanbahadur, M.R. Lanjewar, B.K. 2006. Influence of sowing dates, irrigation levels and mulching on nutrient uptake and yield of mustard cv.ACN-9. J. Soils and Crops, 16(1): 158-164.

Iraddi, V.S. and Mansur, C.P. 2008. Responseof mustard [Brassica juncea (L.)Czern and Cosson] varieties to date of sowing and row spacing in northern transition zone of Karnataka, main Agriculture Research Station University of Agricultural Science, Dharwad. 
Jadhav, S.N. and Singh, N.P. 1992. Water and soil moisture extraction pattern of mustard (Brassica juncea) under varying sowing dates insect pest control measures and irrigation. Indian $J$. Agron., 37(1): 198-200.
Singh, S.K. and Singh, G. 2002. Response of Indian mustard (Brassica juncea) varieties nitrogen under varying sowing dates in eastern Uttar Pradesh. Ind. J. Agron., 47(2): 242-248.

\section{How to cite this article:}

Abhinaw Kumar Singh, Hanumant Singh, Sarware Alam, O.P. Rai and Ghanshyam Singh. 2017. Effect of Sowing Dates and Varieties on Quality and Economics of Indian Mustard (Brassica juncea L.). Int.J.Curr.Microbiol.App.Sci. 6(3): 799-802. doi: https://doi.org/10.20546/ijcmas.2017.603.093 